\title{
TRATAMENTO CIRÚRGICO-ORTODÔNTICO DE DENTES RETIDOS: RELATO DE UM CASO CLÍNICO
}

Osmar MARQEVIX, Leonardo Silva BENATO, Cassia BIRON, Kelston Ulbricht GOMES, João luiz CARLINI

O tratamento cirúrgico-ortodôntico de dentes retidos objetiva a recolocação do dente na arcada dentária, sem causar danos aos outros elementos dentais adjacentes, restabelecendo a estética e a função. $O$ objetivo do trabalho é relatar, através de um caso clínico, a forma de tratamento para o tracionamento do dente canino superior direto incluso apontando a técnica cirúrgica utilizada. A paciente, na segunda década de vida, foi encaminhado da ortodontia para cirurgia de exposição e colagem de dispositivo para posterior tracionamento ortodôntico. Para localizar a posição do dente na arcada, foi utilizada a técnica radiográfica de Clark, onde concluiu-se que se encontrava na região vestibular. A abordagem cirúrgica foi através de uma incisão no rebordo alveolar e duas incisões relaxantes em direção ao fundo de vestíbulo na distal do 14 e mesial do 12. Após a exposição do dente e isolamento do campo com gaze para permitir um campo seco, fizemos a colagem do botão ortodôntico com resina fotopolimerizável. Após 18 meses de tratamento ortodôntico, o dente se encontrava na posição correta.

Palavras-chave: Cirurgia bucal; Dente Canino; Ortodontia 